ВИЗНАЧЕННЯ РІВНЯ ПРОФЕСІЙНОЇ ГОТОВНОСТІ МАЙБУТНІХ ФАХІВЦІВ З ФІЗИЧНОГО ВИХОВАННЯ Й СПОРТУ ДО ПРОФЕСІЙНОЇ ДІЯЛЬНОСТІ В УМОВАХ ІНКЛЮЗИВНОГО НАВЧАННЯ

\title{
DETERMINING THE LEVEL OF PROFESSIONAL READY FOR FUTURE PROFESSIONALS IN PHYSICAL EDUCATION AND SPORTS TO PROFESSIONAL ACTIVITIES IN THE CONDITIONS OF INCLUSIVE SCIENCE
}

УДК 378.147:796-051]:376-056.2/.3 DOI https://doi.org/10.32843/26636085/2020/22-4.33

\section{Скрипка І.М.,}

канд. наук з фіз. виховання і спорту, доцент кафедри теорії та методики спорту

Сумського державного педагогічного університету імені А.С. Макаренка Солоненко Є.В.,

старший викладач кафедри теорії та методики спорту

Сумського державного педагогічного університету імені А.С. Макаренка у статmі визначено необхідність профресійної підготовки кадрів для роботи в умовах інклюзивної освіти. Установлено проблему вдосконалення педагогічної освіти в навчанні майбутніх фрахівців фрізичного виховання й спорту для підвищення якості викладання дисципліни «фрізична культура» в інклюзивних класах. У результаті дослідження підтверджено, що суспільнополітичні зміни в Україні суттєво змінили сутність професійної діяльності вчителів фрізичного виховання, а традиційний зміст, форми й методи підготовки вчителів фрізичного виховання неповною мірою відповідають вимогам сьогодення. Стаття присвячена вивченню професійної готовності майбутніх фрахівців з фрізичного виховання й спорту до роботи з дітьми з особливими освітніми потребами, тому що це є одним із головних завдань держави та закладів вищої освіти, де проходить підготовка фрахівців у галузі фрізичної культури і спорту. Упровадження інклюзивного навчання в Україні та підвищення уваги до осіб з особливими потребами, залучення їх до занять фозичними вправами підтвердили актуальність досліджуваної проблеми.

у статті наголошується, що модифікація змісту професійної підготовки фрахівців 3 срізичного виховання й спорту в профрільних закладах вищої освіти є важливим засобом забезпечення якості освітніх послуг у системі інклюзивної освіти. Вивчення професійної готовності майбутніх фрахівців з фрізичного виховання й спорту до роботи з дітьми з особливими освітніми потребами вказує на те, що більшість студентів потребує особистої підготовки до професійної діяльності в інклюзивному освітньому середовищі. Підтверджено необхідність додаткової практичної підготовки студентів до організаціі й проведення фрізкультурних свят і заходів фрізкультурно-оздоровчої спрямованості безпосередньо для дітей з особливими потребами.

Ключові слова: професійна готовність, профресійна підготовка, діти з особливими освітніми потребами, інклюзивне освітнє середовище, фрахівці з фрізичного виховання i спорту.

The article identifies the need for vocational training for inclusive education. The problem of improvement of pedagogical education in training of the future specialists of physical education and sport for raising the quality of teaching of the discipline "physical culture" in inclusive classes is established. As a result of the research it is confirmed that socio-political changes in Ukraine have significantly changed the essence of professional activity of teachers of physical education, and the traditional content, forms and methods of training of teachers of physical education do not fully meet the requirements of today. The article is devoted to studying the professional readiness of future specialists in physical education and sports to work with children with special educational needs (OOP) because it is one of the main tasks of the state and institutions of higher education (ZVO), where specialists in the field of physical culture and sports are trained. The introduction of inclusive education in Ukraine and increasing the attention to persons with special needs to engage them in physical exercises confirmed the relevance of the problem under study. The article emphasizes that modification of the content of professional training of specialists in physical education and sports in specialized higher education institutions is an important means of ensuring the quality of educational services in the inclusive education system. Studying the professional readiness of future specialists in physical education and sports to work with children with special educational needs (OOP) indicates that most students require personal preparation for professional activity in an inclusive educational environment. The necessity of additional practical preparation of students for the organization and holding of physical culture holidays and activities of physical and health orientation is confirmed, aimed directly at the categories of children with special needs.

Key words: vocational readiness, vocational training, children with special educational needs, inclusive educational environment, specialists in physical education and sports.
Постановка проблеми в загальному вигляді. Розвиток сучасної України й інтеграція в європейський простір висуває нові більш високі вимоги до професійної підготовки фрахівців різних напрямів, що потребує суттєвих змін у професійній підготовці. Проблеми вдосконалення педагогічної освіти існує також у навчанні майбутніх фрахівців фрізичного виховання й спорту, а їх вирішення підвищить якість викладання дисципліни «фрізична культура» в інклюзивних класах. Саме тому в умовах перебудови освітньої сорери підготовка фрахівців високої кваліфрікації з фрізичного виховання та спорту до роботи з дітьми з особливими освітніми потребами (ООП) є одним із головних завдань держави, закладів вищої освіти (далі - 3ВО), де проходить підготовка фрахівців у галузі фрізичної культури і спорту, та суспільства загалом.

За даними І. Малишевської [7], провідною ознакою розвитку сучасної української спеціальної освіти $€$ прагнення до рівного доступу до якісної освіти дітей із особливими освітніми потребами, що $€$ основоположним для інклюзивної освіти. У контексті європейських цінностей інклюзивна освіта вимагає значної переорієнтації свідомості 
педагогічних працівників різних спеціальностей, а також здійснення педагогами своєї профресійної діяльності 3 урахуванням принципів толерантності, поваги до індивідуальних особливостей дітей, неупередженості й недопущення дискримінації [10, с. 5]. За даними Т. Матвійчук [7, с. 5], усупереч педагогічній спрямованості ЗВО галузі ФКіС, чинна система підготовки не забезпечує необхідну професійну підготовку кадрів для роботи в умовах інклюзивної освіти та не забезпечує випускникам рівня педагогічної майстерності, який відповідає соціальному запиту, а проблема вивчення професійної готовності майбутніх фрахівців з фрізичного виховання та спорту до роботи 3 дітьми з особливими потребами залишається мало дослідженою.

Аналіз останніх досліджень і публікацій. У дослідженнях І. Іваній [4] визначає, що фрізичне виховання громадян пов'язано насамперед з особистістю вчителя фрізичної культури, його професійними знаннями, педагогічною майстерністю та професійною компетентністю. Водночас Н. Степанченко [17, с. 7] указує, що традиційний зміст, форми й методи підготовки вчителів фрізичного виховання неповністю відповідають вимогам сьогодення, так як суспільно-політичні зміни, що відбулися в Україні, суттєво змінили сутність профресійної діяльності вчителів фрізичного виховання. О. Форостян, Д. Правдов (2013), О. Силаєва (2016), Є. Приступа, Ю. Петришин, І. Бондар (2013), аналізуючи проблеми впровадження інклюзивного фрізичного виховання, визначили, що суттєвою перешкодою цього процесу є ресрлексія вчителів фрізичної культури.

О Томащук [19] указує, що зміст фрахової підготовки викладачів з фрізичного виховання, тренера 3 виду спорту неповною мірою передбачає фрормування спеціальних умінь і навичок з адаптивної фрізичної культури й адаптивного спорту. Питання специфіки загальних теоретико-методичних основ підготовки вчителів фрізичної культури проаналізовано в дослідженнях Т. Дереки (2017), Н. Степанченко (2017), Л. Сущенко (2003), М. Данилевич (2015); питання щодо теоретико-методичного стану підготовки фахівців фрізичного виховання та спорту до роботи в умовах центрів інваспорту розглунуто О. Томащук (2017); особиста фрізична й мотиваційна готовність до профресійної діяльності в інклюзивному освітньому просторі вивчали Г. Куртова, О. Архипов, М. Короп, В. Гамов, О. Вертель (2017); фрормування готовності до професійної діяльності майбутніх учителів фрізичного виховання досліджують такі провідні науковці, як В. Шафранський (2011), І. Скрипченко (2015), Л. Чалій (2017).

Виділення не вирішених раніше частин загальної проблеми. Готовність майбутніх фрахівців фрізичного виховання та спорту до викладання дисципліни «фізична культура» в школах з інклюзивною фрормою навчання недостатньо досліджено, тому ії вивчення $€$ актуальним.

Мета статті - визначити та проаналізувати готовність майбутніх фрахівців із фрізичного виховання й спорту закладів вищої освіти до роботи з дітьми з особливими освітніми потребами (в умовах інклюзивного освітнього середовища). Для їі досягнення необхідно виконати такі завдання:

1) окреслити сучасний стан профресійної підготовки майбутніх вчителів фрізичної культури та тренерів у вищих навчальних закладах України;

2) розробити форму анкетування для вивчення рівня готовності майбутніх фрахівців фрізичного виховання й спорту до роботи 3 дітьми 3 особливими освітніми потребами;

3) проаналізувати та систематизувати отриманні результати проведеного анкетування серед студентів вищих навчальних закладів 3 проблеми дослідження.

У дослідженнях використовували такі методи: аналіз літературних джерел та інтернет-сайтів, анкетування, методи математичної статистики.

Виклад основного матеріалу. Згідно зі статтею 20 «ннлюзивне навчання» Закону України «Про освіту» [4], заклади освіти зобов'язані утворити інклюзивні класи для навчання особи з особливими освітніми потребами в разі звернення її батьків із заявою про прийняття такої дитини до навчального закладу, а також створити умови для навчання осіб із особливими освітніми потребами відповідно до індивідуальної програми розвитку та з урахуванням їхніх індивідуальних потреб і можливостей.

В Україні практика впровадження інклюзивних фрорм освіти в систему загальноосвітніх навчальних закладів є складною, що пов'язано з наявністю бар'єрів загальної освіти, такими як недостатній рівень компетентності в межах цієї проблеми педагогічного корпусу вищих педагогічних навчальних закладів [8, с. 17]. Характерними рисами сучасної інклюзивної освіти є необхідність удосконалення у ЗВО навчальних програм і методик викладання, тобто повномасштабної підготовки педагогічних фахівців до роботи в умовах інклюзії.

Незважаючи на значну кількість досліджень 3 проблеми професійної підготовки майбутніх фрахівців з фрізичного виховання і спорту, у ЗВО недостатньо приділяється увага її оновленню і проектуванню [4], а впровадження інклюзивного навчання в Україні та підвищення уваги до осіб з особливими потребами, залучення їх до занять фрізичними вправами надають більшої актуальності цій проблемі. О. Томащук [19] указує на необхідність посилення вимог до професійної підготовки майбутніх учителів фрізичного виховання, a саме: модернізацію навчально-педагогічного процесу у 3ВО, зміну структури його організації, детальне проектування професійної підготовки, використання інноваційних технологій навчання. 
Профресійна підготовка фрахівців з фрізичного виховання й спорту в 3 ВО необхідна також для підвищення їхньої профресійної готовності до проведення оздоровчо-спортивних занять з пріоритетним використання елементів різних видів спорту для початкового ознайомлення дітей 3 особливими потребами вже на початку їх навчання, що сприятиме розширенню кола виконуваних рухових дій і дасть їм змогу підвищити свої фрізичні кондиції з метою подальшої інтеграції в повноцінне суспільне життя.

У дослідженнях Н. Агаркової [1] указується, що традиційна загальнопедагогіча підготовка фрахівців для ефективної роботи з дітьми з особливими освітніми потребами недостатня, у більшості педагогів відсутня мотивація до роботи із цією категорією дітей, є страх, бажання уникнути такої роботи. Для подолання цих проблем підтверджується актуальність вирішення завдання сучасної професійної освіти у сфері фрізичної культури і спорту.

За даними А. Молдован [10], такі завдання полягають у тому, щоб навчити майбутнього спеціаліста реалізувати себе в діяльності, сорормувати власний профресійний вигляд та образ (у тому числі й фрізичну культуру особистості), розвинути творчі, духовно-інтелектуальні та психофрізичні здатності, пов'язані з умінням трансорормувати ідеї гуманізму в професійну практику.

Але вирішення завдання сучасної професійної освіти у сорері фрізичної культури і спорту неможливе без вивчення загальнопрофесійних термінів, що безпосередньо стосуються професійної підготовки майбутніх фрахівців з фрізичного виховання та спорту. Л. Гуцул (2015) указує, що одним із актуальних завдань мовної підготовки вчителя $€$ опанування фраховою термінологією, а оволодіння основами будь-якої професії розпочинається із засвоєння системи загальних і професійних знань, опанування майбутнім фрахівцем спеціальної наукового дискурсу профресії.

У педагогічному енциклопедичному словнику «профресійна підготовка» - це система профресійного навчання, яка має на меті прискорене придбання тими, хто навчається, навичок, необхідних для виконання конкретної роботи або групи робіт [10, с. 223]. Педагогічна енциклопедія дає змогу встановити сутнісний зміст поняття «профресійне самовизначення» - процес прийняття рішення особистістю щодо вибору майбутньої трудової діяльності, пов'язаний із фрормуванням професійних інтересів, засвоєнням соціальних норм, виробленням соціальних позицій [18, с. 153].

Так за даними Т. Матвійчук [3, с. 37 ], на основі педагогічного потенціалу в процесі навчання в студентів фрормуються педагогічні знання й уміння, на основі якихуподальшому формуватиметьсяїхня професійно-педагогічна компетентність. У педагогічній енциклопедії зазначено, що й готовність, і компетентність - це рівні професійної педагогічної майстерності [10, с. 68], а взаємозв'язок професійної підготовки та професійної компетентності підтверджують дослідження науковців [4; 10; 17].

Р. Маслюк [8] під поняттям «фрізична культура майбутнього вчителя» визначає таку якість майбутнього вчителя, для формування якої задіяні комплекси заходів, спрямованих на зміцнення здоров'я, загартування організму, гармонійний розвиток фрізичних можливостей особистості, фрормування життєво важливих рухових умінь і навичок. Професійна готовність студента визначається як особистісна якість, яка проявляється в позитивній самооцінці себе як суб'єкта майбутньої професійної діяльності та прагненні займатися нею після закінчення 3ВО, є вирішальною умовою швидкої адаптації випускника до умов праці, подальшого його професійного вдосконалення й підвищення кваліфікації [16, с. 111]. Саме тому актуальним питанням останнім часом $€$ підвищення рівня професійної підготовки фрахівців фрізичного виховання й спорту до організації фрізичного виховання в умовах інклюзивного середовища.

Згідно із Закону України, заклади освіти за потреби утворюють інклюзивні та спеціальні групи й класи для навчання осіб з особливими освітніми потребами [4]. Є. Приступа, Ю. Петришин, І. Боднар [13] виявили відсутність методологічних концепцій загального характеру, що не дає змоги сорормувати науково обґрунтовані технології організаційно-методичного забезпечення інклюзивного фрізичного виховання школярів, скеровані до спеціальної медичної групи в умовах єдиного процесу, як наслідок, ускладнює трансорормацію освітньої політики держави. Тому важливим є впровадження стратегії інклюзивного фрізичного виховання сьогодні, щоб завтра випускники фрізкультурних вузів могли б повноцінно здійснювати її на практиці [13].

Проблема формування відповідного рівня підготовленості кадрів вимагає свого вирішення. І. Боднар [1], Л. Борисенко [2], І. Омельяненко [11], О. Форостян [20] уважають її однією з основних проблем інклюзивного фрізичного виховання й наголошують на нагальному розробленні такого документа з урахуванням інтересів і можливостей усіх дітей, залучених до інклюзивного фрізичного виховання, попри навчання дітей в інклюзивних класах за навчальними планами, програмами, підручниками, посібниками, рекомендованими Міністерством освіти і науки України для загальноосвітніх навчальних закладів.

Складання та реалізація індивідуальної програми розвитку (далі - ІПР) є однією з основних умов для успішного навчання дітей з особливими освітніми потребами в загальноосвітніх навчальних закладах, розробляється ІПР для тих учнів, які потребують певних адаптації та/або модифікацій через особливості сприймання інформації чи 
засвоєння навчального матеріалу. Отже, дитина може мати водночас модифрікації з одного предмета, адаптації - 3 іншого, а з третього - навчатися за загальноосвітньою програмою (якщо їй це дають можливість навички) [4].

В. Шевченко [22] вказує, що для підготовки фрахівців до роботи в інклюзивних умовах необхідна цілеспрямована робота 3 удосконалення знань, методичної підготовки до роботи 3 дітьми з особливими потребами, їх навчання та соціалізації, навчання педагогів співпрацювати з усіма учасниками процесу, працювати в команді потребує подальшого вдосконалення, а також вивчення нового й поширення набутого досвіду. Тому інклюзивне навчання потребує модернізації навчальнометодичного забезпечення й удосконалення відповідної фахової підготовки кадрів для роботи з дітьми з особливими потребами.

У ході дослідження ми провели анкетування студентів II і VI курсів спеціальності 017 «Фізична культура і спорт», 014 Середня освіта «Фізична культура» Сумського державного педагогічного університету імені А.С. Макаренко (СумДПУ імені А.C. Макаренка) та спеціальності 017 «Фізична культура і спорт» Сумського державного університету (СУМДУ) загальною кількістю 324 особи (254 та 70 студентів відповідно). Під час проведення анкетування отримали даніщодо визначення рівня готовності майбутніх фрахівців з фрізичного виховання й спорту до їхньої професійної діяльності в інклюзивному освітньому просторі. Анкетування дало змогу встановити загальний рівень знань майбутніх фрахівців щодо створення рівних умов доступу до освіти дітям 3 особливими освітніми потребами, згідно з відповідями, 75,4\% студентів дали ствердну відповідь, тоді як 24,7\% не мають інформації та знань щодо створення інклюзивного навчання в закладах середньої освіти.

$\mathrm{Ha}$ питання щодо необхідності й ефективності використання засобів фрізичної культури та спорту для інтеграції дитини з особливими освітніми потребами в повноцінне суспільне життя 70,7\% указали, що це є ефрективні засоби, 17,6\% уважають, що дітям з ООПє протипоказання до занять фрізичною культурою та спортом, 10\% не визначилися 3 відповіддю. На необхідність індивідуалізації й диференціації навчального процесу 3 фрізичного виховання та розробки індивідуальних навчальних програм з фрізичної культури вказують $76,5 \%$ студентів, тоді як 15,7\% студентів уважають можливим проведення уроків з фрізичної культури для дітей з особливими потребами за програмою «Фізична культура» для спеціальних медичних груп, 7,8\% не визначилися з відповіддю. Для адаптації змісту та методів навчання на уроках з фрізичної культури 51,2\% майбутніх фрахівців 3 фрізичного виховання й спорту вказують на обов'язкове оцінювання когнітивних і рухових можливостей, а також вивчення особливостей психофрізіологічного розвитку дітей з ООП, тоді як 33,6\% студентів не впевненні в цій необхідності й відповіли, що швидше так, ніж ні; 11,1\% - швидше ні, ніж так, 13,0\% важко відповісти.

У зв'язку з тим що вчитель в інклюзивному класі має не лише організовувати та забезпечувати оптимальні умови навчання, а й створювати сприятливу атмосореру в учнівському колективі для отримання якісного навчання «особливої» дитини, у процесі анкетування респондентам запропоновано оцінити власний рівень підготовленості до роботи з такими дітьми. Більшість студентів - 29,9\% - уважають рівень своєї підготовленості недостатнім; у 33,0\% студентів відповідь - швидше так, ніж ні; 27,2\% - швидше ні, ніж так, 9,9\% не визначилися з відповіддю.

Інклюзія полягає в адаптації системи до потреб дитини, а термін «інклюзивне орізичне виховання» Є. Приступа, Ю. Петришин, І. Боднар [13] тлумачать як гнучку індивідуалізовану систему фрізичного виховання дітей з особливими

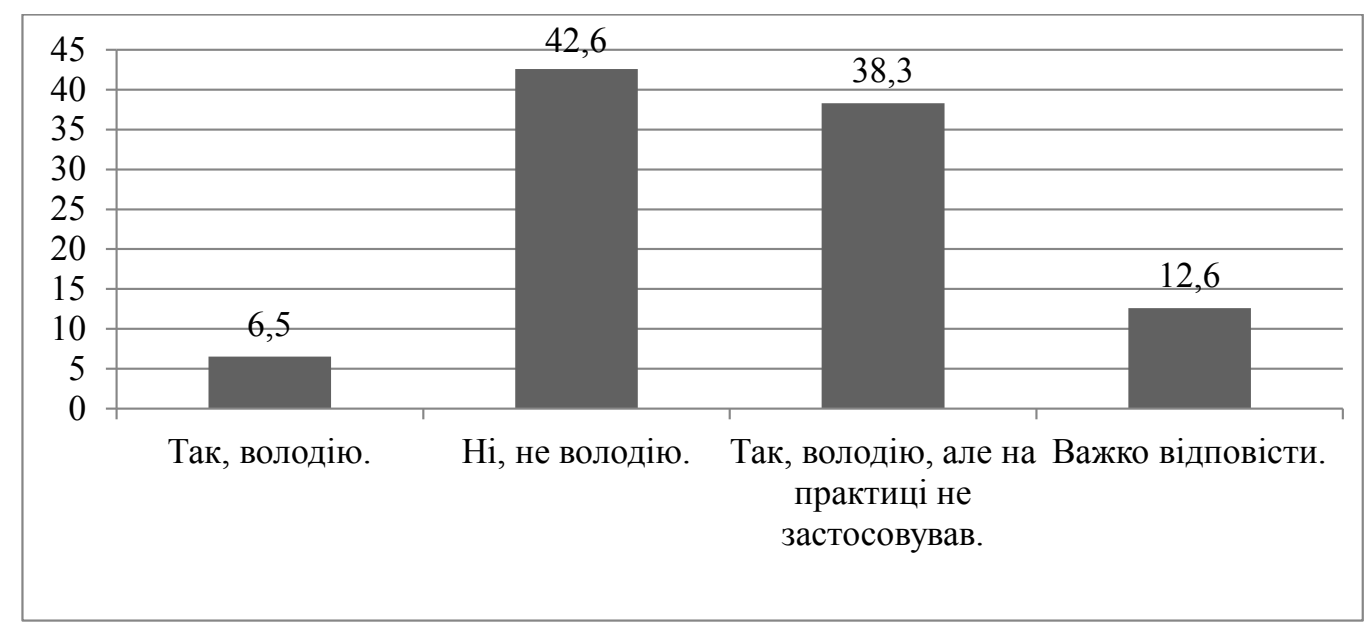

Рис. 1. Вивчення знань студентів щодо здійснення інклюзивного фізичного виховання 

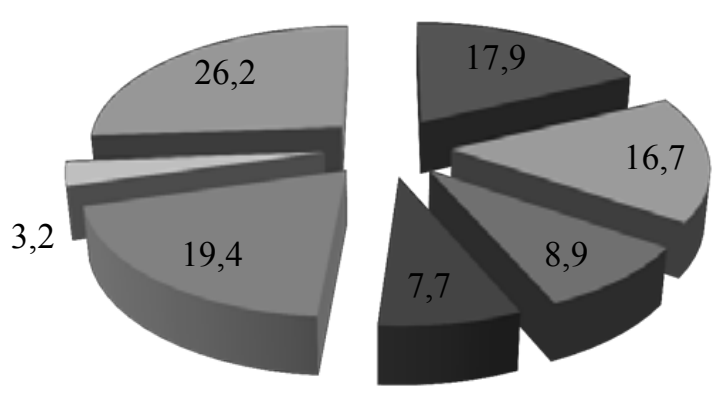

- Адаптивне фізичне виховання

Фізична реабілітація та ЛФК

- ТМФК

— Паралімпійський спорт

п Інклюзивна освіта

- Важко відповісти

- У декількох дисциплінах

Рис. 2. Навчальні дисципліни, у яких розглядають питання інклюзивного фізичного виховання

потребами в умовах масової загальноосвітньої школи. Дані анкетування вказують на необхідність набуття студентами під час навчання в 3 ВО системи знань, умінь і навичок, які в подальшій професійній діяльності забезпечать їхню успішну комунікацію 3 командою фрахівців і 3 батьками дітей для спільного складання індивідуальної програми розвитку дитини з особливими потребами. На питання «Чи володієте Ви знаннями щодо здійснення інклюзивного фрізичного виховання дітей, фрунціональні можливості яких дуже різняться?» отримали такі відповіді (рис. 1).

Проведене дослідження дало змогу зробити висновок, що вищі навчальні заклади забезпечують більш якісну підготовку фахівців для роботи 3 дітьми, які належать до основної медичної групи, тому що 75,3\% опитаних респондентів потребують особистої підготовки до професійної діяльності в інклюзивному освітньому середовищі, лише 21,9\% планують отримати відповідні знання на курсах підвищення кваліфрікації вчителів за необхідності, а 2,8\% важко відповісти.

Визначено, що 52,5\% опитаних отримують недостатньо інфрормації з методики проведення уроків фрізичної культури та організації заходів фрізкультурно-оздоровчої спрямованості для дітей з ООП під час навчання у 3ВО, а 32,4\% студентів отримують інфрормації із цього питання в достатній кількості для їхньої подальшої профресійної діяльності з дітьми в інклюзивних калах, тоді як 15,1\%не визначилися з відповіддю. У 83,3\% студентів є потреба в отриманні додаткової практичної підготовки до організації й проведення фрізкультурних свят і заходів фрізкультурно-оздоровчої спрямованості безпосередньо для категорії дітей з особливими потребами; 13,6\% відповіли, що підготовка їм швидше не потрібна, ніж потрібна; 3,1\% не визначилися 3 відповіддю. На рис. 2 показано, що під час підготовки фрахівців з фізичного виховання й спорту питання побудови процесу фрізичного виховання дітей з особливими потребами окреслюють у таких дисциплінах.

Відповіді на запитання анкети «Чи достатньо сорормовано Ваша особиста готовність до професійної діяльності?» розподілилися так: у 20,7\% студентів достатньо сорормована; 31,2 \% швидше так, ніж ні; 34,3\% - швидше ні, ніж так; 13,3\% - важко відповісти. Проведене дослідження підтверджує дані спеціалістів Г. Куртова, О. Архипова, Ю. Короп, В. Гамова, О.В. Вертель (2017), О. Форостян (2018), що майбутні фрахівці з фрізичного виховання й спорту не готові працювати в інклюзивному класі, так як загальні питання теорії та методики інклюзивної освіти розкриті недостатньо протягом їх навчання в 3ВО.

Висновки. Дослідження підтверджує загострення проблеми підготовки кадрів до профресійної діяльності в інклюзивному освітньому середовищі й проблеми кадрового забезпечення фахівцями зокрема, які здатні проводити уроки з фрізичної культури для дітей, фрізичні можливості яких дуже різняться. Анкетування дало можливість установити рівень професійної готовності майбутніх фрахівців із фрізичного виховання й спорту до роботи в інклюзивному класі, лише 20,7\% студентів уважають рівень своєї готовності достатньо сформований.

Визначено, що 52,5\% опитаних отримують недостатньо інфрормації 3 методики проведення уроків фрізичної культури та організації заходів фрізкультурно-оздоровчої спрямованості для дітей з ООП в навчальному процесі майбутніх фрахівців 3 фрізичного виховання й спорту. Для 83,3\% студентів $€$ потреба в отримані додаткової практичної підготовки до організації й проведення фрізкультурних свят і заходів фрізкультурно-оздоровчої спрямованості безпосередньо для категорії дітей з особливими потребами.

Подальші дослідження полягають у вивченні готовності вчителів фрізичної культури до проведення уроків з фрізичної культури в інклюзивних класах. 


\section{БІБЛІОГРАФІЧНИЙ СПИСОК:}

1. Агаркова Н. Підготовка майбутніх вихователів та вчителів початкових класів до роботи 3 дітьми 3 особливими освітніми потребами. Social Work and Education. 2019. Vol. 6. № 1. P. 70-79.

2. Боднар І.Р. Специфрічні принципи інтегративного фрізичного виховання школярів. Фізичне виховання, спорт і культура здоров'я у сучасному суспільстві : збірник наукових праць. 2015. № 1 (29). С. 5-9.

3. Борисенко Л.Л. Підвищення ефективності процесу фрізичного виховання в умовах інклюзивної освіти. Надання освіти з особливими потребами в умовах інклюзивного освітнього простору : збірник матеріалів Регіональної науково-практичної конференції. Лисичанськ : ВП ЛПК ЛНУ ; ТОВ «КИТ-Л», 2015. С. 23-26.

4. Про освіту : Закон України. 2017. URL: http://zakon4.rada.gov.ua/laws/show/1060-12 [in Ukrainian]

5. Іваній І. Компетентнісний підхід до професійної підготовки вчителя фрізичної культури. Фізичне виховання, спорт і культура здоров'я у сучасному суспільстві : збірник наукових праць. 2013. № 1 (21). C. 42-46.

6. Іщук В. Сутність і структура профресійної підготовки майбутніх учителів фрізичного виховання. Гуманітарний вісник. 2013. № 31. С. 118-122.

7. Малишевська, І. Підготовка спеціальних педагогічних фрахівців до роботи в умовах інклюзивного освітнього середовища. Педагогічні науки: теорія, історія, інноваційні технології : науковий журнал. Суми : Вид-во СумдПУ імені А.С. Макаренка, 2016. № 8 (62). С. 264-274.

8. Маслюк Р. Особливості багаторівневої професійної підготовки майбутніх вчителів фрізичної культури в контексті навчального комплексу «педагогічний коледж-педагогічний університет». Збірник наукових праць Уманського державного педагогічного університету. 2019. Вип. 2. С. 69-77.

9. Матвійчук Т.Ф. Формування педагогічної майстерності майбутніх учителів фрізичного виховання у процесі профресійної підготовки : дис. ... канд. пед. наук : 13.00.04 «Теорія і методика профресійної освіти». Вінниця, 2015. 273 с.

10. Молдаван А.Д. Проблеми підготовки майбутніх фрахівців фрізичної культури та спорту до професійної діяльності у вищих навчальних закладах. Молодий вчений : науковий журнал. 2017. № 3.1 (43.1). С. 213-217.

11. Омельяненко І.О. Дидактичне забезпечення фрізичного виховання школярів у гетерогенних групах в умовах інклюзивної освіти. Збірник наукових праць Хмельницького інституту соціальних технологій Університету «Україна». 2015. № (1). С. 91-94.

12. Педагогический энциклопедический словарь / М.М. Безруких, В.А. Болотов, Л.С. Глебова и др. ; под ред. Б.М. Бим-Бада. Москва : Большая Российская энциклопедия, 2008. 528 с.

13. Підвищення якості та наступність викладання предметів оздоровчо-лікувальної спрямованості при підготовці бакалаврів за фрахом «фрізичне виховання» / Л.В. Подрігало, С.А. Пашкевич, М.І. Галашко, В.А. Тихонова, Г.С. Чесноков, І.В. Сидорко. Вісник Чернігівського національного педагогічного університету імені Т.Г. Шевченка. 2011. № 86 (2). C. 100-106.

14. Порошенко М.А. Інклюзивна освіта : навчальний посібник. Київ : ТОВ «Агентство «Україна», 2019. $300 \mathrm{c}$.

15. Приступа Є.Н., Петришин Ю.В., Боднар І.Р. Інклюзивне фрізичне виховання 1-3 груп здоров'я. Педагогіка, психологія та медико-біологічні проблеми фрізичного виховання і спорту. 2013. № 1. С. 62-67.

16. Приходько Ю.О., Юрченко В.І. Психологічний словник-довідник : навчальний посібник. Київ : Каравела, 2012. 328 с.

17. Садова І. Особливості підготовки майбутнього вчителя до навчання дітей з особливими потребами в освітньому середовищі. Актуальні питання гуманітарних наук. 2015. Вип. 14. С. 313-318.

18. Словник-довідник 3 професійної педагогіки / авт.-упоряд. А.В. Семенова. Одеса : Пальміра, 2006. $272 \mathrm{c}$.

19. Степанченко Н.І. Система профресійної підготовки майбутніх учителів фрізичного виховання у вищих навчальних закладах : дис. ... докт. пед. наук : 13.00.04 / Вінниц. держ. пед. ун-т ім. М. Коцюбинського. Вінниця, 2017. 629 с.

20. Томащук О. Підготовка майбутніх фрахівців 3 адаптивного фрізичного виховання до роботи в центрах інваспорту як педагогічна проблема. URL: http://www.vmurol.com.ua/upload/Naukovo_doslidna\% 20robota/Elektronni_vidannya/Act_problemi/2009/41.pdf.

21. Форостян О. Проблеми організації уроків фрізичної культури в інклюзивному класі. Педагогічні науки: теорія, історія, інноваційні технології. Суми, 2018. № 8 (82). С. 256-264.

22. Шевченко В. Підготовка майбутніх педагогів до роботи в умовах інклюзивної освіти. Humanitarium. 2018. Том 42. Вип. 2. С. 162-170. 